Jurnal BASTRA (Bahasa dan Sastra) : http://ojs.uho.ac.id/index.php/BASTRA

\title{
KEMAMPUAN MENULIS SURAT DINAS SISWA KELAS VII SMP NEGERI 11 KENDARI
}

Oleh

\author{
Meliagustin ${ }^{1}$, Hj. Erny Harijaty ${ }^{2}$, dan Harmin ${ }^{3}$ \\ ${ }^{1}$ Alumni Jurusan Pend. Bahasa dan Sastra Indonesia, ${ }^{2,3}$ Dosen Jurusan \\ Pendidikan Bahasa dan Sastra Indonesia, Fakultas Keguruan dan Ilmu \\ Pendidikan Universitas Halu Oleo
}

\begin{abstract}
ABSTRAK
Tujuan yang ingin dicapai dalam penelitian ini adalah untuk mendeskripsikan kemampuan menulis surat dinas siswa kelas VII SMP Negeri 11 Kendari. Metode yang digunakan dalam penelitian ini adalah metode deskriptif kuantitatif. Populasi dalam penelitian ini adalah keseluruhan siswa Kelas VII SMP Negeri 11 Kendari tahun ajaran 2018/2019 yang terdiri dari 3 kelas yang jumlahnya 89 orang sekaligus ditetapkan sebagai sampel penelitian. Berdasarkan hasil penelitian, dari 89 orang siswa yang menjadi responden penelitian, terhadap 74 orang siswa $(83,14 \%)$ yang memperoleh kategori mampu secara individual dalam menulis surat dinas. Sedangkan 15 orang siswa $(16,85 \%)$ memperoleh kategori tidak mampu secara individual dalam menulis surat dinas. Hal tersebut dapat disimpulkan bahwa siswa kelas VII SMP Negeri 11 Kendari dalam menulis surat dinas dikategorikan tidak mampu. Dikatakan demikian, karena secara klasikal kemampuan siswa kelas VII SMP Negeri 11 Kendari dalam menulis surat dinas hanya mencapai $83,14 \%$ dan tidak mencapai criteria ketuntasan klasikal yaitu $85 \%$.
\end{abstract}

Kata kunci: kemampuan, menulis, surat dinas 


\section{PENDAHULUAN}

\subsection{Latar Belakang}

Pembelajaran bahasa Indonesia di sekolah ditekankan pada aspek membina, mengembangkan pengetahuan, dan keterampilan berbahasa yang bertujuan agar semua peserta didik mampu dan terampil berkomunikasi baik lisan maupun tulisan. Keempat aspek keterampilan berbahasa yaitu, membaca, menulis, berbicara, dan menyimak perlu diajarkan secara terpadu dengan menggunakan bahasa Indonesia yang baik dan benar. Pembelajaran merupakan suatu proses perilaku individu dalam interaksi dirinya dengan lingkungannya.

Pembelajaran bahasa Indonesia dalam kurikulum 2013 secara umum bertujuan agar siswa mampu mendengarkan, membaca, memeriksa, berbicara, dan menulis. Kompetensi dasar tersebut dapat di kembangkan berdasarkan tiga hal yang saling berhubungan dan saling mendukung mengembangkan pengetahuan siswa (Harsiati, 2017: 2).

Tujuan Pembelajaran bahasa Indonesia yaitu agar peserta didik mampu memiliki kompetensi bahasa Indonesia untuk berbagai fungsi komunikasi dalam berbagi kegiatan sosial. Selain itu pembelajaran bahasa Indonesia diharapkan dapat menumbuhkan minat baca dan minat menulis. Sehubungan dengan tujuan tersebut, pembelajaran bahasa Indonesia dikembangkan berdasarkan pendekatan komunikatif, berbasis teks, dan pendekatan pendidikan karakter (Harsiati, 2017: 3).

Kemampuan menulis adalah salah satu kemampuan berbahasa yang harus dimiliki oleh siswa. Untuk menulis, siswa memerlukan berbagai pengalaman dan pengetahuan mengenai hal pokok tentang apa yang ditulis dan bagaimana menulis.

Pembelajaran menulis surat dinas merupakan salah satu cara untuk membuat siswa menjadi lebih terampil berkomunikasi secara tertulis kepada orang lain maupun instansi. Sehingga siswa pun dapat mengasah kemampuan pada aspek menulis. Kemampuan tersebut mencakup pengetahuan tentang hal yang akan ditulis dan bagaimana menuangkan ide, pikiran, dan gagasan yang dimiliki ke dalam tulisan.

Menurut Tarigan (1986:21) menulis adalah menurunkan atau melukiskan lambang-lambang grafik yang menggambarkan suatu bahasa yang dipahami oleh seseorang, sehingga orang-orang lain dapat membaca lambang-lambang grafik tersebut. Menulis bukanlah sesuatu yang mudah karena untuk dapat menghasilkan tulisan yang baik siswa dituntun memiliki kemampuankemampuan yang lain. Kemampuan tersebut mencakup pengetahuan tentang hal yang akan ditulis dan bagaimana menuangkan ide, pikiran, dan gagasan yang dimiliki ke dalam tulisan.

Komunikasi secara tidak langsung dapat dilakukan dengan menggunakan bahasa tulis. Sarana komunikasi tertulis yang dapat digunakan untuk menyampaikan informasi kepada pihak lain adalah surat.

Surat adalah suatu sarana untuk menyampaikan pernyataan atau informasi secara tertulis dari pihak yang satu ke pihak yang lainnya. Surat bertujuan untuk menyampaikan informasi secara tertulis kepada penerima pesan/pihak lain. Surat memiliki berbagai macam, salah satunya adalah surat dinas. 
Surat dinas adalah surat yang berisi masalah-masalah kedinasan. Umumnya surat ini dikeluarkan oleh kantor atau jabatan pemerintah. Menulis surat dinas adalah suatu aktivitas seseorang dalam menuangkan ide-ide, pikiran, dan perasaan secara logis dan sistematis dalam bentuk tertulis yang berhubungan dengan kedinasan sehingga pesan tersebut dapat dipahami oleh para pembaca. Tujuan menulis surat dinas yaitu untuk mengirim suatu pesan yang berisi perseorangan formal kelembagaan ke suatu instansi (Kosasih, 2009: 9).

SMP Negeri 11 Kendari merupakan salah satu sekolah yang sudah menerapkan kurikulum 2013 dalam proses pembelajaran. Salah satu materi pembelajaran menulis pada semester 2 di kelas VII SMP Negeri 11 Kendari adalah menulis surat dinas yang tercantum dalam Kompetensi Dasar (KD) 4.12 Menulis Surat (Pribadi dan dinas) untuk kepentingan resmi dengan memperhatikan struktur teks, kebahasaan, dan isi. Dalam buku siswa edisi revisi 2017 materi tentang menulis surat dinas meliputi: struktur surat dinas (kepala surat/kop surat, nomor surat, tanggal surat, lampiran, hal atau perihal, alamat surat, salam pembuka, isi surat, salam penutup, nama organisasi, nama terang dan tanda tangan penanggung jawab surat, tembusan).

Pada penguasaan keterampilan menulis khususnya pembelajaran menulis surat dinas, siswa diharapkan mampu menulis surat dinas sesuai sistematika yang diajarkan. Untuk mengetahui kemampuan siswa dalam menulis surat dinas, pada saat proses pembelajaran berlangsung harus memperhatikan kondisi dan suasana dalam kelas agar tidak gaduh dalam proses pembelajaran. Selai itu, berdasarkan keterangan salah satu guru bahasa Indonesia di sekolah tersebut mengemukakan bahwa penelitian tentang menulis surat dinas bagus dilaksanakan agar nantinya dapat mengetahui kemampuan siswa dalam menulis surat dinas.

Penulis tertarik untuk meneliti mengenai menulis surat dinas sesuai dengan penulisan struktur surat dinas. Sebagai masyarakat pelajar yang sering mempelajari mengenai penulisan surat dinas, peneliti hendak menguji sejauh mana kemampuan siswa dalam menulis surat dinas. Alasan lain memilih menulis surat dinas sebagai instrumen penelitian, didasari suatu pertimbangan bahwa menulis surat dinas telah diajarkan pada siswa kelas VII SMP Negeri 11 Kendari. Selain itu, di sekolah tersebut belum pernah diadakan penelitian tentang kemampuan menulis khususnya menulis surat dinas.

Berdasarkan penjelasan tersebut penulis tertarik untuk melakukan penelitian dengan judul "Kemampuan Menulis Surat Dinas Siswa Kelas VII SMP Negeri 11 Kendari”.

\subsection{Rumusan Masalah}

Sehubungan dengan latar belakang di atas, yang menjadi masalah dalam penelitian ini adalah bagaimanakah kemampuan menulis surat dinas siswa Kelas VII SMP Negeri 11 Kendari?

\subsection{Tujuan Penelitian}

Tujuan yang ingin dicapai dalam penelitian ini adalah untuk mendeskripsikan kemampuan menulis surat dinas siswa kelas VII SMP Negeri 11 Kendari. 


\subsection{Manfaat Penelitian}

Hasil penelitian ini diharapkan dapat memberikan manfaat sebagai berikut:

1. Penelitian ini dapat berguna sebagai bahan masukan bagi pengajar, khususnya di SMP Negeri 11 Kendari untuk mengarahkan kemampuan siswa dalam keterampilan menulis, khususnya dalam menulis surat dinas.

2. Bagi siswa, dapat menjadi sarana pembelajaran dalam menulis surat dinas.

3. Bagi sekolah, sebagai masukan untuk meningkatkan kualitas pembelajaran di kelas, khusunya pembelajaran menulis surat dinas.

4. Bagi peneliti selanjutnya, hasil penelitian ini dapat digunakan sebagai pertimbangan atau masukan untuk kegiatan penelitianpenelitian selanjutnya yang sesuai atau sehubungan dengan penelitian menulis surat dinas.

\subsection{Ruang Lingkup}

Ruang lingkup dalam penelitian ini fokus penulisan surat difokuskan pada pengembangan penulisan surat dinas berdasarkan struktur surat yang tertera dalam buku siswa bahasa Indonesia revisi 2017 yaitu (kop surat, tanggal surat, nomor surat, lampiran, perihal, alamat, salam pembuka, isi, salam penutup, nama dan tanda tangan, dan tembusan).

\section{KAJIAN PUSTAKA}

\subsection{Hakikat Menulis}

\subsubsection{Pengertian Menulis}

Menulis, menurut Sumarjo (dalam Komaidi, 2017: 15) merupakan suatu proses melahirkan tulisan yang berisi gagasan. Banyak yang melakukannya secara spontan, tetapi juga ada yang berkali-kali mengadakan koreksi dan penulisan kembali.

Menurut Tarigan (dalam Said, 2017: 2) menulis adalah suatu keterampilan berbahasa yang dipergunakan untuk berkomunikasi secara tidak langsung, tidak secara tatap muka dengan orang lain. Menulis pada hakikatnya adalah menuangkan gagasan, pendapat, perasaan, keinginan, dan kemauan serta informasi ke dalam bahasa tulis, kemudian mengirimkannya kepada orang lain Syafi'ie, (dalam Said, 2017: 2).

Menurut Rosidi (2009: 2) menulis merupakan kegiatan untuk menyatakan pikiran dan perasaan dalam bentuk tulisan yang diharapkan dapat dipahami oleh pembaca dan berfungsi sebagai alat komunikasi secara tidak langsung.

Menurut Suparno dan M. Yunus (dalam Said, 2017: 2) mengemukakan bahwa menulis dapat didefinisikan sebagai salah satu kegiatan penyampaian pesan (komunikasi) dengan menggunakan bahasa tulis sebagai alat atau media.

Berdasarkan pendapat beberapa ahli di atas dapat disimpulkan, bahwa menulis adalah suatu keterampilan berbahasa dalam menuangkan ide/gagasan, pendapat, perasaan, keinginan serta informasi ke dalam bentuk tulisan dengan pola pengembangan dan tujuan tertentu.

\subsubsection{Tujuan Menulis}

Hartig (dalam Soebachman, 2016: 16-17) merumuskan tujuan menulis sebagai berikut.

1. Tujuan penugasan, sebenarnya tidak memiliki tujuan karena orang yang menulis melakukannya 
karena tugas yang diberikan kepadanya.

2. Tujuan altruistik, penulis bertujuan untuk menyenangkan pembaca, menghindarkan kedudukan pembaca, ingin menolong pembaca memahami, menghargai perasaan dan penalarannya, ingin membuat hidup para pembaca lebih mudah dan lebih menyenangkan dengan karyanya itu.

3. Tujuan persuasif, penulis bertujuan meyakinkan para pembaca akan kebenaran gagasan yang diutarakannya.

4. Tujuan informasional, penulis bertujuan memberikan informasi atau keterangan kepada para pembaca.

\subsubsection{Manfaat menulis}

Selain memiliki tujuan, menulis juga memiliki manfaat. Dengan demikian banyak hal yang didapatkan. Suparno dan M. Yunus (dalam Said, 2017: 7-9) menyatakan beberapa manfaat menulis sebagai berikut:

1. Menulis dapat mengembangkan daya inisiatif dan kreatif. Dengan menulis, pengetahuan akan bertambah khususnya berkaitan dengan unsur mekanik tulisan, seperti bahasa, ejaan, dan tanda baca.

2. Menulis dapat menyumbangkan kecerdasan. Dengan menulis dapat melahirkan pengetahuan dan pengalaman yang luas.

3. Menulis dapat menumbuhkan keberanian dan rasa percaya diri.

Selain itu, menurut Abigail (2015: 4-5) manfaat menulis dapat diurakan sebagai berikut:

1. Sarana untuk mengungkapkan diri.

2. Sarana untuk pemahaman.
3. Mengembangkan kepuasan pribadi, kebanggaan, dan perasaan harga diri.

4. Meningkatkan kesadaran dan terhadap lingkungan.

5. Keterlibatan secara bersemangat. Berdasarkan pendapat di atas dapat disimpulkan bahwa manfaat menulis yaitu dapat mengembangkan pengetahuan dan dengan menulis dapat menambah pemahaman bagi seseorang.

\subsection{Pengertian Surat}

Menurut Komaidi (2017: 211) surat adalah sehelai kertas yang digunakan untuk mengadakan komunikasi secara tertulis. Adapun isi surat dapat berupa pernyataan, keterangan, pemberitahuan, laporan, permintaan, pertanyaan, sanggahan, tuntutan, gugatan, protes, dan sebagainya Silmi (dalam Komaidi, 2017: 211).

Menuru Rahardjo (1994: 75) surat merupakan media komunikasi yang paling banyak dipakai oleh manusia dalam berkomunikasi (sering dikenal sebagai korespondensi).

Menurut Rahardjo (1994: 75) surat menyurat merupakan komunikasi tertulis yang kita kenal sebagai korespondensi. Surat diartikan sebagai sebagai setiap kertas tertulis atau tercetak yang dibuat oleh seseorang atau orang-orang lain tertentu dengan maksud menyampaikan berita atau pendapat yang tercantum pada kertas tersebut.

Menurut Finoza (1991: 3) surat adalah alat untuk menyampaikan suatu maksud secara tertulis. Berdasarkan pendapat diatas dapat disimpulkan bahwa surat adalah sehelai kertas yang digunakan dalam media komunikasi terlulis yang dipakai oleh manusia untuk berkomunikasi. 


\subsection{Fungsi Surat}

Surat mempunyai pengertian sebagai satu sasaran umtuk menyampaikan pernyataan atau informasi secara tertulis dari pihak yang satu ke pihak yang lain (Rahardjo, 1994: 76). Informasi yang disampaikan (dikomunikasikan) dapat berupa pemberitahuan, pernyataan, pertanyaan, permintaan, laporan, pemikiran, sanggahan, dan sebagainya.

Menurut Rahardjo, (1994: 76-

77) surat sebagai alat komunikasi mempunyai beberapa fungsi yaitu:

1. Tanda bukti tertulis yang autentik, misalnya surat perjanjian.

2. Alat pengingat/berpikir bilamana diperlukan, misalnya surat yang telah diarsipkan.

3. Dokumentasi historis, misalnya surat dalam surat arsip lama yang digali kembai untuk mengetahui kejadian masa lampau.

4. Jaminan keamanan, misalnya surat keterangan jalan.

5. Pedoman atau dasar bertindak, misalnya surat keputusan, surat perintah, surat perangkatan, dan sebagainya.

Selain itu, menurut Komaidi (2017: 212) surat berfungsi sebagai berikut.

1. Sarana komunikasi. Sesuai dengan fungsinya, surat merupakan sarana komunikasi yang ekonomis dan praktis.

2. Wakil. surat menjadi wakil dari pembuatan surat yang membawa pesan, misi atau informasi yang hendak disampaikan kepada penerima.

3. Bahan bukti. Mengingat surat merupakan informasi tertulis, maka surat dapat dijadikan bahan bukti yang mempunyai kekuatan hukum.

4. Sumber data. Surat dapat digunakan menjadi sumber data yang dapat digunakan untuk informasi atau petunjuk keterangan untuk ditindak lanjuti.

5. Surat dapat menjadi surat jaminan, seperti jaminan keamanan pada surat jalan, jaminan tanggungan pada surat gadai, dan sebagainya.

Berdasarkan pendapat diatas, dapat disimpulkan bahwa fungsi surat yaitu sebagai sarana komunikasi ekonomi atau tanda bukti tertulis dan dapat dijadikan bahan bukti yang mempunyai kekuatan hukum.

\subsubsection{Jenis-Jenis Surat}

Menurut Rahardjo (1994: 77-79) secara garis besar surat dapat digolongkan menurut isi dan nasal pengirimannya, maksud dan tujuannya, wujudnya, banyaknya sasaran yang hendak dicapai, jaminan dan keamanan isinya, dan urgensi penyelesaiannya.

1. Menurut isi dan nasal pengirimannya, surat dapat dibedakan menjadi; (a) surat pribadi adalah surat yang ditujuhkan kepada perseorangan atau pribadi, yang isinya bisanya menyangkut hubungan pribadi, (b) Surat resmi atau surat dinas pemerintah adalah surat yang biasa di gunakan dalam aktifitas perkantoran, di mana dapat berupa surat dari satu kantor ke kantor lain, atau dari perseorangan/pribadi ke suatu kantor atau sebaliknya. Karena surat ini bersifat resmi, maka bahasa yang dipakai bersifat lugas langsung pada permasalahan dan seperlunya saja, (c) surat niaga atau dagang adalah surat yang digunakan dalam kegiatan niaga atau perdagangan atau perusahaan.

2. Menurut maksud dan tujuannya, surat digolongkan atas: (a) surat pemberitahuan,

(b) surat 
keputusan, (c) surat perintah, (d) surat pemerintaan atau permohonan, (e) surat peringatan atau teguran, (f) surat panggilan, (g) surat penawaran, (h) surat perjanjian, (i) surat pesanan, (j) surat laporan, (k) surat pengantar/jalan, (l) surat lamaran pekerjaan, (m) surat penegasan, (n) surat penntutan (klaim), dan sebagainya.

3. Menurut wujudnya, dikenal bentuk-bentuk surat seperti kartu pos, warkat pos, surat bersampul, nota atau memo, telegram, telex, dan sebagainya.

4. Menurut banyaknya sasaran yang hendak dicapai, surat terbagi atas surat biasa, surat edaran, dan pengumuman.

5. Berdasarkan jaminan dan keamanan isinya, dikenal empat macam surat, yaitu: (a) surat sangat rahasia, (b)surat rahasia, (c) surat terbatas dan (d) surat biasa

6. Menurut urgensi penyelesaiannya, surat terbagi atas surat kilat khusus, surat (kilat), surat segera, dan surat biasa.

7. Menurut prosedurnya, surat dapat digolongkan menjadi surat masuk dan surat keluar.

8. Berdasar jangkauannya, surat diklasifiksikan menjadi: surat intem dan surat eksterm.

9. Menurut nilai isi surat, surat dapat dibagi menjadi: surat rutin dan surat non-rutin.

10. Berdasarkan kegunaannya, surat dapat dikelompokan menjadi: (a) kosep, (b) asli, (c) tembusan/tindasan/kopy, $\quad$ (d) petikan, turunan/kutipan/salinan, lampiran.

11. Menurut cara pengirimannya, surat dapat dibedakan: (a) dibawah sendiri, (b) dengan kurir, (c) pos antar departeman.

\subsection{Bentuk-Bentuk Surat}

Menurut Rahardjo (1994: 81-87) surat adalah tata letak atau posisi bagian-bagian surat. Masing-masing bagian surat mempunyai posisi tertentu sesuai dengan fungsi dan perannya, terutama sebagai petunjuk atau identifikasi untuk memproses surat tersebut. Ada berbagai bentuk surat, yang satu sama lain berbeda pemakaiannya sesuai dengan kebiasaan instansi atau gaya masyarakat tertentu, meskipun pada dasarnya hanya ada dua bentuk pokok.

1. Bentuk lurus/balok (block style) yang sering dikenal sebagai gaya Amerika, adalah bentuk surat dimana setiap baris alinea rata kiri. Bentuk lurus atau balok ini ada 2 macam; yaitu lurus penuh (full block style) dan setengah lurus (semi block style).

2. Bentuk lekuk/indentasi (indented style) adalah bentuk surat di mana setiap alinea ujungnya masuk (indented) ke kanan beberapa ketukan spasi.

3. Bentuk alinea menggantung (hanging paragraph style) adalah bentuk surat dimana setiap ujung alinea berada disebelah kiri ujung baris berikutnya, sehingga terlihat seakan baris selanjutnya menggantung pada baris pertama tersebut.

4. Bentuk resmi atau dinas (official style) biasa mempunyai ciri selalu ada nomor, pokok soal (perihal), dan lampiran (bila ada).

\subsection{Syarat Surat yang Baik}

Menurut Surono, dkk (2012: 135136) surat yang baik harus memenuhi syarat yang baik yaitu sebagai berikut : 
1. Menggunakan bentuk surat yang standar, artinya penyusunan bagian-bagian harus tetap sesuai dengan aturan yang telah ditentukan.

2. Menggunakan bahasa Indonesia baku, artinya bahasa dalam surat harus memperhatikan kaidah pemakaian ejaan, kaidah pilihan kata, dan kaidah penyusunan kalimat.

3. Menyatakan isi surat dengan ringkas dan jelas agar penerima surat dapat memahami isi surat secara tepat.

\subsection{Surat Dinas}

Menurut Soedjito (2016: 14) surat dinas adalah surat yang berisi masalah kedinasan atau administrasi pemerintah. Surat dinas hanya dibuat oleh instansi pemerintah dan dapat dikirimkan kepada semua pihak yang memiliki hubungan dengan instansi tersebut.

Menurut Raharjo (1994: 79) surat dinas adalah surat yang biasa digunakan dalam aktifitas perkantoran, dimana dapat berupa surat dari satu kantor lain atau dari peseorangan/pribadi ke suatu kantor atu sebaliknya. Menurut Kosasih (2009: 9) surat dinas adalah surat yang berisi masalah-masalah kedinasan.

Berdasarkan pendapat diatas, dapat disimpulkan bahwa surat dinas adalah surat yang berisi kedinasan atau perkantoran yang di kirimkan kepada semua pihak yang memiliki hubungan dengan instansi tersebut.

\subsubsection{Struktur Surat Dinas}

Menurut Raharjo (1994: 88-99) mengemukakan struktur surat dinas terdiri atas:

1. Kepala surat/kop
Kepala surat/kop yaitu digunakan untuk mengetahui nama dan keterangan lain mengenai badan atau organisasi atau perusahaan yang mengirim surat tersebut. Kepala surat biasanya di tulis bagian tengah dengan menuliskan nama kantor/jabatan/perusahaan, alamat, nomor telepon, dan nomor kotak pos (jika ada).

2. Tanggal surat

Tanggal surat adalah keterangan yang menjelaskan lokasi atau waktu ditulisnya surat. Penulisan tanggal surat tidak perlu didahului oleh nama tempat/kota karena nama tersebut telah tercantum pada kepala surat.

Contoh;

1 Januari 2015

1 Juni 2013

3. Nomor surat (No.)

Nomor surat meliputi nomor urut penulisan surat, kode surat, dan angka tahun. Nomor surat atau kode pada surat dinas berguna untuk memudahkan pengaturannya dan penyimpanannya sebagai arsip, memudahkan penunjukan pada waktu mengadakan hubungan surat menyurat, dan memudahkan mencari surat kembali surat tersebut bila mana diperlukan.

Contoh:

No: 200/PBJJ-BI/1984 $(\mathrm{PBJJ}-\mathrm{BI}=$ Program Belajar Jarak Jauh Bidang Studi Bahasa Indonesia)

4. Lampiran (Lamp.)

Lampiran yaitu surat yang melampirkan sesuatu (kuitansi, brosur, atau fotokopi berkas). Kata lampiran dicantumkan di sebelah kiri atas di bawah kata "nomor" dan tidak menyebutkan jenisnya satu persatu.

Contoh; 
Lamp.: 1 berkas atau satu berkas

5. Hal atau perihal

Bagian ini menunjukan isi atau inti surat secara singkat. Dengan membaca Hal/Perihal, secara tepat dapat diketahui masalah yang dituliskan dalam surat itu. Hendaknya Hal/Perihal dituliskan secara singkat dan jelas.

Contoh;

No. : 007/DIR/SK/1990

Lamp.: Satu berkas

Hal : Jadwal ujian ulangan

6. Alamat surat

Alamat yang dituliskan ada dua yaitu alamat luar yang tertera pada sampul dan alamat dalam yang tercantum pada surat itu sendiri. Penulisan alamat baik untuk alamat luar maupun dalam, sebaiknya menyebut nama orang yang dituju, dengan mencantumkan sebutan "Saudara, Bapak, Ibu,Tuan dll) tergantung pada siapa surat itu dikirim. Namun bila pengirim mau menyebutkan jabatan, pangkat, atau gelar akademis penerima surat, maka ia hanya menuliskan jabatan, pangkat atau gelar didahului sebutan Bapak, Nyonya, saudara, dan sebagainya.

Contoh:

Yth. Kepala Kampus LPP Yogyakarta

7. Salam pembuka

Salam pembuka merupakan tanda hormat penulis sebelum memulai pembicaraan.

Contoh:

Dengan hormat,

8. Isi surat

Isi surat juga sering disebut tubuh surat yang terdiri atas pembuka, isi surat, dan penutup. (1) pembuka pada surat bersifat pemberitahuan, pernyataan, permintaan, pernyataan, atau laporan (2) isi surat atau pokok surat yang sesungguhnya memuat sesuatu yang di beritakan, dilaporkan, ditanyakan, dinyatakan, diminta atau sebagainya, (3) penutup merupakan kesimpulan dan berfungsi sebagai kunci isi surat atau penegasan isi surat yang mengandung harapan penulis atau ucapan terima kasih terhadap hal yang disampaikan dalam isi surat.

9. Salam penutup

Salam penutup dicantumkan diantara penutup dan tanda tangan. fungsinya untuk menunjukan rasa hormat dan keakraban pengirim terhadap penerima surat.

Contoh:

Hormat kami,

Salam kami,

Wassalam,

10. Nama dan tanda tangan

Surat yang ditanda tangani oleh pejabat yang berhak atau oleh orang lain atas nama pejabat yang berwenang adalah sah. Yang berwenang yang menanda tangani surat dalam suatu organisasi adalah pemimpin yang bertanggung jawab atas organisasi tersebut.

11. Tembusan

Tembusan ditulis sebelah kiri bawah, lurus ke atas dengan nomor, lampiran, dan hal/perihal.

Contoh:

Kepada Kantor Depdikbud Kodya Malang.

\subsubsection{Ciri-Ciri Bahasa Surat Dinas}

Menurut Harsiati, dkk (2017: 236) adapun penggunaan bahasa pada surat dinas yaitu sebagai berikut:

1. Pilihan kata sapaan bersifat formal.

2. Bahasa yang jelas.

3. Menggunakan bahasa formal.

4. Pemilihan kata baku. 


\subsubsection{Isi Surat Dinas}

Menurut Hasriati (2017: 250) isi surat dinas berkaitan dengan topik kedinasan. Misalnya, undangan rapat, permohonan maaf suatu instansi kepada orang/instansi/perusahaan, lamaran pekerjaan, surat permintaan izin tidak masuk, izin menggunakan tempat, dan sebagainya. Surat dinas hanya boleh ditulis oleh sebuah instansi kepada instansi lain atau individu. Penulisan surat dinas tergantung pada kaidah kebahasaan dan menggunakan bahasa formal.

\subsection{Kriteria Penulisan Surat}

Menurut Finoza (1991: 6-7) kriteria dan ciri umum surat yang baik adalah:

1. Menggunakan kertas surat yang tepat dari segi ukuran, jenis, dan warna sesuai dengan surat yang akan ditulis.

2. Menggunakan bentuk surat yang standar.

3. Menggunakan bahasa yang baku.

4. Menggunakan bahasa yang jelas.

5. Menggunakan bahasa yang sopan dan hormat.

\subsection{Pembelajaran Menulis}

Menurut Rosidi (2009: 2-3) dalam pembelajaran menulis terdapat empat keterampilan berbahasa yang diterima oleh seseorang secara berurutan. Keterampilan tersebut adalah menyimak, berbicara, membaca dan keterampilan menulis. Keempat keterampilan berbahasa tersebut dalam pembelajaran harus mendapat porsi yang seimbang dan pelaksanaannya dilakukan secara terpadu serta intensif. Menulis merupakan sebuah kegiatan menuangkan pikiran dan perasaan dalam bentuk tulisan yang diharapkan dapat dipahami oleh pembaca dan berfungsi sebagai alat komunikasi secara tidak langsung.

\subsection{Pembelajaran Menulis Surat Dinas Siswa Kelas VII SMP Negeri 11 Kendari}

Pembelajaran menulis surat dinas sangatlah penting dipelajari karena dalam pelaksanaan pembelajaran siswa diajarkan untuk memahami suatu bacaan atau yang akan ditulis, bertujuan agar siswa dapat menulis suatu karangan serta tidak keluar dari gagasan atau pembicaraan yang disampaikan.

dinas termuat dalam materi pembelajran SMP Kelas VII. Selain itu materi menulis struktur surat dinas sudah diajarkan di sekolah tersebut. Pembelajaran menulis surat dinas termuat dalam buku guru, buku siswa dan mengacu pada silabus serta mengikuti kurikulum 2013. Pembelajaran menulis surat dinas tercantum dalam silabus dengan Kompetensi Dasar 4.12 Menulis surat (pribadi dan dinas) untuk kepentingan resmi dengan memperhatikan struktur teks, kebahasaan, dan isi, dengan indikator yaitu menulis surat dinas, dengan memperhatikan struktur/bagian-bagian surat dinas (kop surat, tanggal, nomor, lampiran, perihal, alamat, salam pembuka, isi, salam penutup, nama dan tanda tangan, dan tembusan). Alokasi waktunya yaitu 2x40 menit (2 jam pelajaran) untuk satu kali pertemuan.

Materi pembelajaran di SMP Negeri 11 Kendari sesuai dengan kurikulum 2013 tentang menulis surat dinas, mengacu pada buku guru dan buku siswa. Adapun materi pembelajaran menulis surat dinas yaitu menulis struktur/bagian surat dinas (kepala surat/kop, nomor surat, tanggal surat, lampiran, hal atau perihal, 
alamat surat, salam pembuka, isi surat, salam penutup, nama organisasi, nama terang dan tanda tangan penanggung jawab surat, tembusan).

\section{METODE PENELITIAN}

\subsection{Jenis dan Metode Penelitian}

\subsubsection{Jenis Penelitian}

Ditinjau dari jenisnya, penelitian ini dikategorikan penelitian lapangan. Dikatakan demikian, karena data penelitian ini diperoleh di sekolah dengan keterlibatan langsung peneliti ke sekolah peneliti.

\subsubsection{Metode Penelitian}

Metode yang digunakan dalam penelitian ini berupa metode deskriptif kuantitatif. Deskriptif yaitu mendeskripsikan data penelitian secara objektif tentang kemampuan siswa kelas VII SMP Negeri 11 Kendari dalam menulis surat dinas, sedangkan kuantitatif maksudnya adalah data yang terkumpul diolah berdasarkan prinsip-prinsip statistik.

\subsection{Populasi dan Sampel Penelitian}

\subsubsection{Populasi}

Populasi dalam penelitian ini adalah seluruh siswa kelas VII SMP Negeri 11 Kendari tahun ajaran 2018/2019 yang berjumlah 89 siswa yang tersebar dalam tiga kelas.

\subsubsection{Sampel Penelitian}

Teknik yang digunakan dalam pengambilan sampel dalam penelitian ini adalah teknik total sampling. Hal ini didasari dengan pendapat Arikunto (2002: 112) yang menyatakan bahwa apabila subjek penelitian kurang dari 100, maka lebih baik diambil semua sehingga penelitiannya berupa penelitian populasi (total sampling) dan jika subjek penelitiannya besar, dapat diambil antara 10-15\% atau 20$25 \%$ atau lebih.

\subsection{Instrumen Penelitian}

Instrumen yang digunakan sebagai alat pengumpulan data yang dalam penelitian ini adalah tes kemampuan menulis surat dinas dalam bentuk teks tertulis. Dalam instrumen penelitian ini siswa di berikan judul yang sudah ditentukan masing-masing siswa untuk membuat surat dinas. Siswa akan diberikan tugas untuk menulis surat dinas, dimana Anda selaku pengurus OSIS akan mengadakan kegiatan perkemahan dan bermaksud untuk meminta permohonan izin kepada Kepala Lurah Sambuli untuk menggunakan lapangan kelurahan dan sekitarnya. Instrumen penelitian yang digunakan dalam penelitian yaitu dengan memperhatikan aspek struktur surat dinas (kop surat, tanggal surat, nomor surat, lampiran, perihal, alamat, salam pembuka, isi surat, salam penutup, nama dan tanda tangan dan tembusan).

Tingkat kemampuan digambarkan melalui skor perolehan siswa pada aspek tersebut. Cara pemberian skor pada hasil kerja siswa dilakukan dengan menggunakan pedoman penskoran atau instrumen penilaian kemampuan menulis surat dinas.

\subsection{Teknik Pengumpulan Data}

Pengumpulan data dilakukan dengan menggunakan tes. Langkahlangkah yang dipergunakan dalam pengumpulan data penelitian ini adalah sebagai berikut:

1. Mengecek atau memeriksa objek penelitian yang hadir dalam kelas.

2. Memberikan penjelasan/petunjuk tentang materi menulis surat pribadi.

3. Memberikan penjelasan tentang petunjuk mengerjakan. 
4. Memberikan lembar kerja.

5. Siswa mengerjakan tugas yang telah diberikan dengan waktu yang disediakan 2 x 40 menit.

6. Mengumpulkan lembar kerja siswa.

\subsection{Teknik Analisis Data}

Teknik analisis data yang digunakan dalam penelitian ini adalah teknik statistik deskriptif dengan presentase. Data kuantitatif yang dikumpulkan yaitu berupa hasil tes menulis surat dinas siswa kelas VII SMP Negeri 11 Kendari. Untuk mengetahui tingkat kemampuan menulis surat dinas di SMP Negeri 11 Kendari, peneliti bepedoman pada kriteria ketuntasan minimal atau KKM pembelajaran bahasa Indonesia yang berlaku di sekolah tersebut yaitu 70 . Sedangkan untuk menentukan kemampuan individual siswa dalam menulis surat dinas dengan menentukan ketuntasan belajar siswa secara klasikal

\section{HASIL PENELITIAN}

\subsection{Deskripsi Pelaksanaan \\ Penelitian}

Penelitian ini dilaksanakan pada tanggal 30, 31, 1, dan 4 Februari 2019 yang bertempat si SMP Negeri 11 Kendari. Jumlah sampel dalam penelitian yang tersebar ke dalam 3 kelas yaitu 89 siswa.

\subsection{Deskripsi Hasil Penelitian}

Nilai kemampuan menulis surt dinas siswa kelas VII SMP Negeri 11 Kendari, berdasarkan data yang dikumpulkan melalui tes, diperoleh kemampuan siswa sebagai berikut.

1. Terdapat 74 orang siswa $(83,14 \%)$ yang peroleh kategori mampu.
2. Terdapat 15 orang siswa $(16,87 \%)$ yang memperoleh kategori tidak mampu.

\subsubsection{Deskripsi Kemampuan Menulis Kop Surat dalam Surat Dinas}

Berdasarkan hasil pengolahan data tentang kemampuan menulis surat dinas pada aspek menulis kop surat dalam surat dinas menunjukan bahwa dari 89 orang siswa kelas VII MP Negeri 11 Kendari, sebanyak 65 orang siswa $(73,03 \%)$ yang secara individual masuk kategori mampu dan sebanyak 24 orang siswa $(26,96 \%)$ dikategorikan tidak mampu. Untuk lebih jelasnya dapat dilihat pada tabel berikut.

\subsubsection{Deskripsi Menulis Tanggal}

Surat

Berdasarkan hasil pengolahan data tentang kemampuan menulis surat dinas pada aspek tanggal surat menunjukan bahwa dari 89 orang siswa kelas VIISMP Negeri 11 Kendari, sebanyak 45 orang siswa $(50,56 \%)$ yang secara individual masuk kategori mampu dan sebanyak 44 orang siswa $(49,43 \%)$ dikategorikan tidak mampu. Untuk lebih jelasnya dapat dilihat pada tabel berikut.

\subsubsection{Deskripsi Kemampuan \\ Menulis Nomor Surat}

Hasil pengolahan data tentang kemampuan menulis surat dinas pada aspek nomor surat menunjukan bahwa dari 89 orang siswa kelas VII SMP Negeri 11 Kendari, sebanyak 79 orang siswa $(88,76 \%)$ yang secara individual masuk kategori mampu dan sebanyak 10 orang siswa $(11,23 \%)$ dikategorikan tidak mampu. Untuk 
lebih jelasnya dapat dilihat pada tabel berikut.

\subsubsection{Deskripsi Kemampuan}

\subsubsection{Menulis Lampiran Surat}

Berdasarkan pengolahan data tentang kemampuan menulis surat dinas pada aspek menulis lampiran surat menunjukan bahwa 89 orang siswa kelas VII SMP Negeri 11 Kendari, sebanyak 82 orang siswa $(92,13 \%)$ yang secara individual masuk kategori mampu dan sebanyak 7 orang siswa $(7,86 \%)$ dikategorikan tidak mampu. Untuk lebih jelasnya dapat dilihat pada tabel berikut.

\subsubsection{Deskripsi Kemampuan \\ Menulis Perihal}

Berdasarkan hasil pengolahan data tentang kemampuan menulis surat dinas pada aspek perihal bahwa dari 89 orang siswa kelas VII SMP Negeri 11 Kendari, sebanyak 71 orang siswa $(79,77 \%)$ yang secara individual masuk kategori tidak mampu dan sebanyak 18 orang siswa $(20,22 \%)$ dikategorikan tidak mampu. Untuk lebih jelasnya dapat dilihat pada tabel berikut.

\subsubsection{Deskripsi Kemampuan Menulis Alamat Surat}

Berdasarkan hasil pengolahan data tentang kemampuan menulis surat dinas pada aspek alamat surat bahwa dari 89 orang siswa kelas VII SMP Negeri 11 Kendari, sebanyak 50 orang siswa $(56,17 \%)$ yang secara individual masuk kategori mampu dan sebanyak 39 orang siswa $(43,82 \%)$ dikategorikan tidak mampu. Untuk lebih jelasnya dapat dilihat pada tabel berikut.

\subsubsection{Deskripsi Kemampuan}

Menulis Salam Pembuka

Berdasarkan hasil pengolahan data tentang kemampuan menulis surat dinas pada aspek salam pembuka surat bahwa dari 89 orang siswa kelas VII SMP Negeri 11 Kendari, sebanyak 78 orang siswa $(87,64 \%)$ yang secara individual masuk kategori mampu dan sebanyak 11 orang siswa $(12,35 \%)$ dikategorikan tidak mampu. Untuk lebih jelasnya dapat dilihat pada tabel berikut.

\subsubsection{Deskripsi Kemampuan Menulis Isi Surat}

Berdasarkan hasil pengolahan data tentang kemampuan menulis surat dinas pada aspek isi surat bahwa dari 89 orang siswa kelas VII SMP Negeri 11 Kendari, sebanyak 63 orang siswa $(70,78 \%)$ yang secara individual masuk kategori mampu dan sebanyak 26 orang siswa $(29,21 \%)$ dikategorikan tidak mampu. Untuk lebih jelasnya dapat dilihat pada tabel berikut.

\subsubsection{Deskripsi Kemampuan}

\section{Menulis Salam Penutup Surat}

Berdasarkan hasil pengolahan data tentang kemampuan menulis surat dinas pada aspek salam penutup surat bahwa dari 89 orang siswa kelas VII SMP Negeri 11 Kendari, sebanyak 67 orang siswa $(75,28 \%)$ yang secara individual masuk kategori mampu dan sebanyak 22 orang siswa $(24,71 \%)$ dikategorikan tidak mampu. Untuk lebih jelasnya dapat dilihat pada tabel berikut.

\subsubsection{Deskripsi Kemampuan Menulis Nama dan Tanda Tangan}


Berdasarkan hasil pengolahan data tentang kemampuan menulis surat dinas pada aspek nama dan tanda tangan surat bahwa dari 89 orang siswa kelas VII SMP Negeri 11 Kendari, sebanyak 58 orang siswa $(65,16 \%)$ yang secara individual masuk kategori mampu dan sebanyak 31 orang siswa $(34,83 \%)$ dikategorikan tidak mampu. Untuk lebih jelasnya dapat dilihat pada tabel berikut.

\subsubsection{Deskripsi Kemampuan Menulis Tembusan Surat}

Berdasarkan hasil pengolahan data tentang kemampuan menulis surat dinas pada aspek tembusan surat bahwa dari 89 orang siswa kelas VII SMP Negeri 11 Kendari, sebanyak 45 orang siswa $(50,56 \%)$ yang secara individual masuk kategori mampu dan sebanyak 44 orang siswa $(49,43 \%)$ dikategorikan tidak mampu. Untuk lebih jelasnya dapat dilihat pada tabel berikut.

\subsection{Interpretasi Hasil Penelitian}

Ramgkuman Data Kemampuan Menulis Surat Dinas Siswa Kelas VII SMP Negeri 11 Kendari

\begin{tabular}{|l|l|l|}
\hline $\begin{array}{l}\text { Aspek } \\
\text { Mampu }\end{array}$ & $\begin{array}{l}\text { Tingkat } \\
\text { Mampu }\end{array}$ & Kategori \\
\hline Kop Surat & $73,03 \%$ & Tidak Mampu \\
\hline $\begin{array}{l}\text { Tanggal } \\
\text { Surat }\end{array}$ & $50,56 \%$ & Tidak Mampu \\
\hline Nomor & $88,76 \%$ & Mampu \\
\hline Lampiran & $92,13 \%$ & Mampu \\
\hline Perihal & $79,77 \%$ & Tidak Mampu \\
\hline Alamat & $56,17 \%$ & Tidak Mampu \\
\hline $\begin{array}{l}\text { Salam } \\
\text { Pembuka }\end{array}$ & $87,64 \%$ & Mampu \\
\hline Isi & $70,78 \%$ & Tidak Mampu \\
\hline $\begin{array}{l}\text { Salam } \\
\text { Penutup }\end{array}$ & $75,28 \%$ & Tidak Mampu \\
\hline $\begin{array}{l}\text { Nama dan } \\
\text { Tanda }\end{array}$ & $65,16 \%$ & Tidak Mampu \\
\hline
\end{tabular}

297 |Jurnal BASTRA (Bahasa dan Sastra), Vol. 4 No. 2, Edisi April 2019/e-ISSN: 2503-3875/ http://ojs.uho.ac.id/index.php/BASTRA

\begin{tabular}{|l|l|l|}
\hline Tangan & & \\
\hline Tembusan & $50,56 \%$ & Tidak Mampu \\
\hline
\end{tabular}

\section{PENUTUP}

\subsection{Simpulan}

Berdasarkan hasil analisis data dapat disimpulkan bahwa kemampuan menulis surat dinas siswa kelas VII SMP Negeri 11 Kendari termaksud dalam kategori tidak mampu. Hal ini dibuktikan dengan persentase perolehan siswa secara klasik (keseluruhan) sebesar 83,14\% yang seharusnya mencapai $85 \%$ dari standar nilai ketuntasan klasikal yang telah ditentukan. Dengan rincian; dari 89 yang dijadikan sampel terdapat 74 orang siswa $(83,14 \%)$ yang dikategorikan mampu dan 15 orang siswa $(16,85 \%)$ masuk kategori tidak mampu. Dilihat dari tingkat kemampuan siswa kelas VII SMP Negeri 11 Kendari pada setiap aspek penilaian yaitu aspek kop surat, tanggal surat, perihal, alamat, isi, salam penutup, nama dan tanda tangan, dan tembusan, tindak tuntas secara klasikal, sedangkan aspek nomor surat, lampiran dan salam penutup tuntas secara klasikal karena persentasenya telah mencapai kriteria ketuntasan minimal yaitu $85 \%$.

\subsection{Saran}

Dari simpulan hasil penelitian yang di paparkan di atas, disarankan hal-hal yaitu untuk lebih meningkatkan kemampuan menulis surat dinas siswa kelas VII SMP Negeri 11 Kendari disarankan untuk guru mata pelajaran bahasa Indonesia memberikan penjelasan dan pemahaman lebih detail kepada siswa mengenai materi pembelajaran menulis surat dinas 
beserta contoh yang mudah dipahami oleh siswa.

\section{DAFTAR PUSTAKA}

Abigail, Monica. 2015. Belajar Menulis. Surabaya: Jp Books.

Arikunto, Suharsimi. 2002. Prosedur

Penelitian Satuan Pendekatan

Praktek. Jakarta: PT Rineka

Cipta.

Finoza, Lamuddin. 1991. Aneka Surat

Sekretaris. Jakarta: Mawar

Gempita.

Harsiati, Titik, dkk. 2017. Buku Siswa

Bahasa Indonesia SMP/MTS

Kelas VII

Edisi Revisi 2017. Jakarta: Pusat

Kurikulum dan Perbukuan

Balitbang, Kemendikbud.

Harsiati, Titik, dkk. 2017. Buku Guru

Bahasa Indonesia SMP/MTS

Kelas VII

Edisi Revisi 2017.Jakarta: Pusat

Kurikulum dan Perbukuan,

Balitbang, Kemendikbud.

Jihad, Asep dan Abdul Haris. 2013.

Evaluasi Pembelajaran.

Yogyakarta: Multi Pressindo.

Komaidi, Didik. 2017. Panduan

Lengkap Menulis Kreatif.

Yogyakarta: Araska.

Kosasi, E. 2003. Ketatabahasaan dan

Kesusastraan. Bandung:

CV.YRAMA WIDYA.

Kosasih, E dan Yoce Aliah Darma.

2012. Menulis Surat Dinas

Lengkap.

Bandung: CV.YRAMA WIDYA.
Rahardjo, Budi. 1994. Surat Menyurat dengan WordStar Professional.

Yogyakarta: Andi Offset.

Rosidi, Imron. 2009. Menulis Siapa

Takut?. Yogyakarta: Kanisius (Anggota IKAPI).

Soebachman, Agustina. 2016. Mahir Menulis dalam 4 Hari. Yogyakarta: Kauna Pustaka.

Said, Rahmat. 2017. Penggunaan Bahasa Indonsia yang Benar pada Karya Ilmia. Kendari: Metro Graphia.

Sujarweni, Wiratna. 2014. Metodolog Penelitian. Yogyakarta: Pustak aBaru Press.

Surono, dkk. 2012. Bahasa Indonesia untuk Perguruan Tinggi. Semarang: Fasindo Press.

Soedjito dan Solichin TW. 2016. Surat Menyurat Resmi Indonesia. Bandung: PT REMAJA ROSDAKARYA.

Sugiyono .2013. Metode Penelitian Pendidikan Pendekatan

Kuantitatif Kualitatif dan RND. Bandung: Alfabeta.

Tarigan, Hendri Guntur. 1986. Menulis Sebagai Suatu Keterampilan Berbahasa. Bandung: Angkasa. 